\title{
Morphogenetic and population structure of two species marine bivalve (Ostreidae: Saccostrea cucullata and Crassostrea iredalei) in Aceh, Indonesia
}

\author{
MUTIA RAMADHANIATY ${ }^{1, \vartheta}$, ISDRAJAD SETYOBUDIANDI ${ }^{2}$, HAWIS H. MADDUPPA ${ }^{1, \vee v}$ \\ ${ }^{1}$ Department of Marine Science and Technology, Faculty of Fisheries and Marine Sciences, Institut Pertanian Bogor. Marine Center Building, Jl Agatis \\ No. 1, Bogor 16680, West Java, Indonesia. Tel.: +62-251-8622-907, Fax.: +62-251-8622-909. ^^email: hawis@apps.ipb.ac.id, madduppa@gmail.com \\ ${ }^{2}$ Department of Aquatic Resources Management, Faculty of Fisheries and Marine Science, Institut Pertanian Bogor. Marine Center Building, Jl Agatis \\ No. 1, Bogor 16680, West Java, Indonesia.
}

Manuscript received: 28 December 2017. Revision accepted: 6 May 2018.

\begin{abstract}
Ramadhaniaty M, Setyobudiandi I, Madduppa HH. 2018. Morphogenetic and population structure of two species marine bivalve (Ostreidae: Saccostrea cucullata and Crassostrea iredalei) in Aceh, Indonesia. Biodiversitas 19: 978-988. Oysters (Family Ostreidae) are mollusks, with high levels of phenotypic plasticity and wide geographic distribution. Oysters are a challenging group for morphological identification and genetic populations study. Saccostrea cucullata and Crassostrea iredalei are oysters from bivalve class that lives in the intertidal area and mangrove ecosystem. To clarify the morphology, genetic diversity and population structure of the two forms of $S$. cucullata and $C$. iredalei, we collected and studied oysters from three locations along the coastal region of Aceh by using morphometric method and $16 \mathrm{~S}$ mtDNA sequences analysis. We also added more oysters sequences from China, Japan, and Thailand to determine the connectivity between all populations. Morphometric characteristics of the oyster showed a negative allometric growth pattern, which means the rate of length gain is faster than that of the weight gain. The genetic distance from $S$. cucullata was $0.003-$ $0.004\left(F_{s t}=0.708\right)$ and $C$. iredalei was $0.000\left(F_{s t}=0.971\right)$. The long genetic distance and high fixation index $\left(F_{s t}\right)$ in the oysters population are caused by the close geographical distance of the species in the three populations. The haplotype diversity value from $S$. cucullata and $C$. iredalei were 20 and 3, respectively. The haplotype showed the connectivity among the oyster populations which indicated by the gene flow pattern. The gene flow was affected by geographical distance and environmental complexity.
\end{abstract}

Keywords: 16S mtDNA, genetic, morphometric, oyster, tiram $\square$

\section{INTRODUCTION}

Morphometric characters and genetic analysis of oysters are the combinations of information about the effects of environmental (Abidin et al. 2014) and geographic conditions that can distinguish the size and genetic variation of oysters (Lam and Morton 2006). Growth is a three-dimensional process that changes over time. Oysters have an irregular shell shape and their growth is strongly influenced by biotic, abiotic factors (Gaspar et al. 2002), environmental, and geographical factors causing high variations in the formation of oyster shells (Gunter 1950; Gosling 2003). High-level phenotypic plasticity in oyster morphology is often of limited value for unambiguous identification of specimens and taxonomy as a whole (Boudry et al. 2003). Accordingly, identification of oyster species based on morphological characters alone is extremely difficult and insufficient (Klinbunga et al. 2005; Jiafeng et al. 2014). A factor that differentiates one oyster species from another is the shell. However, it is difficult to distinguish the shell shape due to its similarity (Boudry et al. 2003). Morphometric is an analysis based on measurements of shell's length and weight (Mass et al. 1999). The length-weight relationship may indicate the stock composition to estimate the availability of oyster sizes, mortality, growth, reproduction, and life cycle in the aquatic environment, providing information about the range of oyster size that should be caught (Fafioyye 2005).

Various oysters live in Aceh coastal, such as Saccostrea cucullata and Crassostrea iredalei. Oysters are benthic marine species inhabiting intertidal areas and widely distributed throughout the tropical and subtropical regions (Hedgecock et al. 1995). Oyster has two weeks pelagic larval duration before it becomes a pediveliger larva that has feet to search for suitable substrate and grow into an adult oyster (Gosling 2003). Long larval dispersal distance combined with other factors has often caused uncertainty in gene flow between a wide geographic range of many oyster species (Buroker 1985; Boudry et al. 2003). The larvae dispersal pattern will lead to high levels of genetic variability within populations of intertidal species (Grassle 1972). Aceh coastal in the northern part of Sumatra is situated in a region with three different types of currents. The western part of Aceh water is associated with the Indian Ocean, the northern part with the Andaman Sea and the eastern part with the Malacca Strait (Nurhayati 2009). The geographic difference causes differences in the distribution and characteristics of marine biota among the three coastal sections. The physical oceanography factors such as currents and tides greatly affect the pattern of dissemination and recruitment of marine biota (Findly and White 2003) 
Rapid species identification, proper management, and availability of stocks are important to avoid local extinction (Madduppa et al. 2017). In recent years, molecular techniques have become essential tools for identification of marine species (Boudry et al. 2003; Madduppa et al. 2014; Prehadi et al. 2015; Kusuma et al. 2016; Maulid et al. 2016). Molecular techniques have been proven to overcome the flaw of morphological identification approach (Boudry et al. 1998) and is widely used to answer questions that cannot be answered ecologically (Madduppa et al. 2016). The use of molecular DNA eases the systematic and identification of oyster species as well as the knowledge of their geographical range (Boudry et al. 2003). Mitochondrial DNA (mtDNA) is a single molecule that evolves more rapidly than the nuclear DNA. Therefore, it is suitable and recommended to be used for DNA barcoding (Hebert et al. 2003). DNA barcoding is an efficient method used to identify species level and plays a role in taxonomy as well as population structure (Hajibabaei et al. 2007). The 16S mtDNA used in this research was based on other previous studies on oysters. Genetic diversity determines population capacity to adapt to the environment (Taylor and Aarssen 1988). A population with high genetic diversity has a better chance of survival because every gene has a different response to environmental conditions (Akbar et al. 2014). Various researches on oyster molecular systematics have been conducted in several countries in the world such as by Klinbunga et al. (2005) who combined the analysis of CO2, $16 \mathrm{~S}$ and $18 \mathrm{~S}$ rDNA of oysters in Thailand; Liu et al. (2011) identified oysters using mitochondrial DNA; Sekino et al. (2014) used mitochondrial DNA of Crassostrea in Japanese waters. The results of those studies answered the researchers' doubts about oyster species. By combining morphological and molecular data, a previous study even successfully found a new species of oyster namely $C$. hongkongensis (Lam and Morton 2003).

Oysters have great economic importance (Christo et al. 2010) and are consumed by people because of its good taste and high protein content (Ruesink et al. 2005). Oyster has been a source of livelihood for Aceh people for a long time. Oyster fishing activities are carried out daily, and as the numbers of fisherman increase, oysters become difficult to grow up normally. In Aceh, this activity has affected oyster populations and led to changes in oyster population structure (Octavina et al. 2014). In our present study, we analyzed morphological characters, genetic diversity, the population structure of oysters between and within populations to understand the wide-scale connectivity of the oyster population.

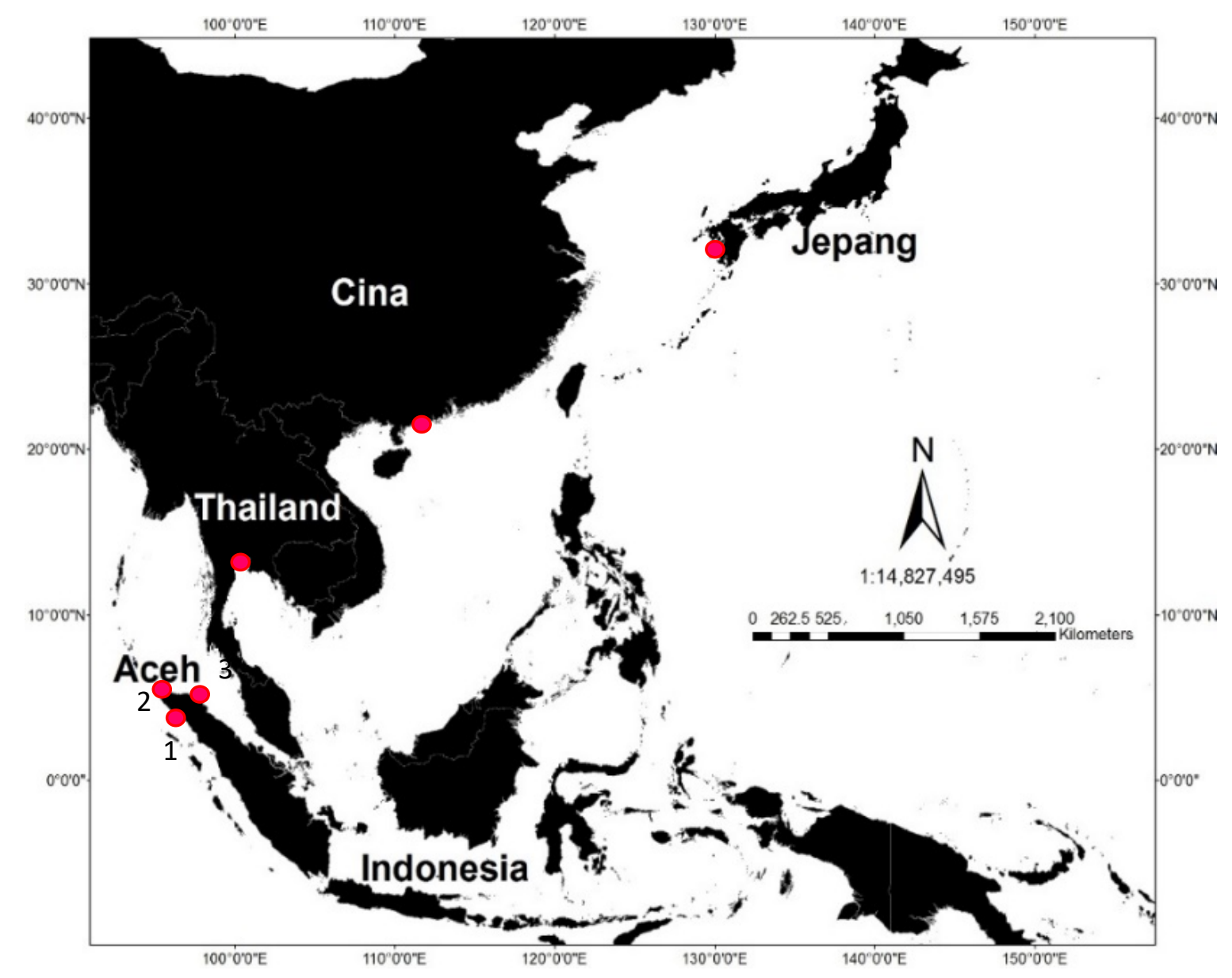

Figure 1. Research sites of S. cucullata and C. iredalei in Aceh Coastal area, Indonesia: 1. Labuhan Haji $6^{\circ} 24^{\prime} 46.8^{\prime \prime}$ S97 $36^{\prime} 43.2^{\prime \prime} \mathrm{E}$, 2. Kuala Gigieng 6 $6^{\circ} 33^{\prime} 57.6^{\prime \prime} \mathrm{S} 98^{\circ} 6^{\prime} 47.88^{\prime \prime} \mathrm{E}$ ), and 3. Loskala $3^{\circ} 41^{\prime} 22.2^{\prime \prime}$ S97 9' 3.6" E ), and sequences from China, Japan dan Thailand obtained from Genbank 


\section{MATERIALS AND METHODS}

\section{Study area and sampling}

Oysters were collected from three sites in Aceh namely Labuhan Haji (South Aceh), Kuala Gigieng (Aceh Besar) dan Loskala (Lhokseumawe) (Figure 1). Labuhan Haji is a region in South Aceh that faces the Indian Ocean, the sampling location at this site was around the Fishing Market. Kuala Gigieng is a site located in Aceh Besar that is adjacent to the Andaman Sea; this site is close to the settlement area and mangrove area. Loskala is an area in North Aceh precisely at Lhokseumawe, and the sampling site is nearby fish ponds.

The sampling was conducted from June 2016 to July 2016. A total of 77 samples were collected from three observation sites using Purposive Random Sampling (Sulistiyarto et al. 2007). Samples were collected when the lowest tides were in the intertidal area of the mangrove ecosystem. The samples were then identified morphologically by using identification book of Poetiers (1998) and Dharma (2005) as references. The length and weight of oysters were measured. Subsequently, oyster samples were removed from their shells, then placed into tubes containing $96 \%$ ethanol.

\section{DNA extraction, amplification, and DNA sequencing $\square$}

For DNA isolation, an adductor muscle of oyster was dissected from the sample and extracted using Extractions kit GeneJet Genomic DNA Purification Kit and gSYNC TM DNA Extraction Kit (Thermo Fisher, Waltham, MA, USA) (Liu et al. 2011). The molecular marker used in this study was $16 \mathrm{~S}$ mtDNA. Amplification of a partial 16S segment by PCR was done using a primer pair F, 5'-CGC CTG TACA AAC AA AT-3'; and R 5'-GGT CTAAC TCA GAT CAG ATC ACG T-3 ') (Banks et al. 1993, Small and Chapman 1997). PCR reaction was set up in a total volume of $25 \mu \mathrm{L}$, containing 1-3 $\mu \mathrm{L}$ of DNA template, $1.25 \mu \mathrm{L}$ of Kapa Master Mix (Kapa Biosystems, Wilmington, MA, USA), $1.25 \mu \mathrm{L}(10 \mathrm{mM})$ of each primer, and $9 \mu \mathrm{L} \mathrm{ddH} 2 \mathrm{O}$. The PCR condition is as follows: denaturation at $95^{\circ} \mathrm{C}$ for 2 min by 30 cycles, denaturation at $95{ }^{\circ} \mathrm{C}$ for $1 \mathrm{~min}$, annealing at $57{ }^{\circ} \mathrm{C}$ for $1 \mathrm{~min}$, extension at $72^{\circ} \mathrm{C}$ for $1 \mathrm{~min}$ and the final extension at $72{ }^{\circ} \mathrm{C}$ for 5 min (Bank et al.1993).The PCR product was assessed by electrophoresis in $1.0 \%$ agarose containing Ethidium Bromide (EtBr). The electrophoresis was done at $100 \mathrm{~V}$ and $400 \mathrm{~mA}$ for 25 minutes and then visualized using a Gel Doc machine. Positively-amplified PCR products were then sent to a sequencing service company (First Base Malaysia) to be sequenced using the Sanger et al. (1977).

\section{Data analysis}

Morphometric length-weight relationship

The oyster shell morphometric was performed by analyzing the length and weight of oysters. The length-toweight ratio was calculated to investigate the growth pattern of oyster using the following equations (Effendie 1997):
$\mathrm{W}=\mathrm{aL}^{\mathrm{b}}$

Where:

$\mathrm{W}=$ Body weight $($ gram $)$

$\mathrm{L}=$ Body length $(\mathrm{mm})$

$\mathrm{a}$ and $\mathrm{b}=$ Constants

The equation is changed into a linear form, as follows:

$\log y=a \log x+\log b$

$\log \mathrm{b}=\frac{\sum \log y \cdot \sum(\log x) \cdot \sum \log x \sum(\log x \cdot \log y)}{\sum(\log x) 2-\left(\sum \log x\right) 2}$

Explanation:

$\log \mathrm{b}=\frac{\sum \log y-N \log b}{\sum \log x}$

The determination of oyster growth criteria is performed by using the length-to-weight ratio based on the $b$ value that is: when $b<3$, the length is greater than the weight, a negative allometric. When $b>3$, the weight is greater than the length, a positive allometric. When $b=3$, the length increase, and the weight gain are balanced or called isometric (Effendie 1997).

\section{Genetic diversity}

Sequences from 77 individual oysters and additional 20 oysters 16S gene sequences from Genbank were aligned and edited in MEGA 6 software (Tamura et al. 2013). The sequences were aligned (Clustal W) to determine the homologous region of those sequences. A phylogenetic tree was constructed based on Neighbour-Joining method, Kimura 2 evolution model and 1000x bootstraps replication (Tamura et al. 2013). Additional oyster sequences from China, Japan, and Thailand were obtained from GenBank, National Center for Biotechnology Information (NCBI), as additional data to know the connectivity and genetic distance of the oysters on a wide scale in Asia. The analysis of genetic diversity (Nei 1987) and nucleotide diversity (Nei and Jin 1989) were calculated using Arlequin program (Schneider et al. 2000).

\section{Genetic population structure and connectivity}

The population structure of molecular variance was analyzed using AMOVA (Excoffier et al. 1992), pairwise using the difference of the subdivision of genetic distance in the population using Fixation index $\left(\mathrm{F}_{\mathrm{st}}\right)$. Both statistical differences between populations and Chi-square probability test for population differentiation were tested using 1000 permutations from data estimated using DNASP (Hudson et al. 1992). Population connectivity was analyzed using PopART software with Median-Joining method (Bandelt et al. 1999). 
Tabel 1. Additional sequence of oyster that was used in this research from China, Japan dan Thailand

\begin{tabular}{|c|c|c|c|}
\hline Species $\square$ & Lokasi & $\begin{array}{l}\text { Acc. } \\
\text { Genebank }\end{array}$ & References \\
\hline \multirow[t]{13}{*}{ S. cucullata } & China & AF458901.1 & Lam and Morton 2003 \\
\hline & & AF458902.1 & Lam and Morton 2003 \\
\hline & & AF458903.1 & Lam and Morton 2003 \\
\hline & & AF458904.1 & Lam and Morton 2003 \\
\hline & & AF458905.1 & Lam and Morton 2003 \\
\hline & & AF458906.1 & Lam and Morton 2003 \\
\hline & Jepang & AB748908.1 & Sekino and Yamashita 2013 \\
\hline & & AB748909.1 & Sekino and Yamashita 2013 \\
\hline & & AB748910.1 & Sekino and Yamashita 2013 \\
\hline & & AB748911.1 & Sekino and Yamashita 2013 \\
\hline & & AB748912.1 & Sekino and Yamashita 2013 \\
\hline & & AB748913.1 & Sekino and Yamashita 2013 \\
\hline & & AB748914.1 & Sekino and Yamashita 2013 \\
\hline \multirow[t]{6}{*}{ C. iredalei } & Jepang & AB972008.1 & Sekino and Yamashita 2013 \\
\hline & & AB972007.1 & Sekino and Yamashita 2013 \\
\hline & Thailand & EF122386.1 & Bussarawit et al. 2006 \\
\hline & & EF122385.1 & Bussarawit et al. 2006 \\
\hline & & EF122384.1 & Bussarawit et al. 2006 \\
\hline & & EF122387.1 & Bussarawit et al. 2006 \\
\hline
\end{tabular}

\section{RESULTS AND DISCUSSION}

\section{Allometric growth of the oyster populations in Aceh}

The morphological characteristics of the oyster in this study are described by the morphometric of length-toweight ratio of oyster shell. The morphometric data of oyster samples from the three study sites are summarized in Table 2. The weight calculation of $S$. cucullata in Labuhan Haji, Kuala Gigieng and Loskala was $\mathrm{W}=0.1311 \mathrm{~L}^{2.9203} \mathrm{R}^{2}$ $=0.1831, \mathrm{~W}=0.2508 \mathrm{~L}^{2.774} 4 \mathrm{R}^{2}=0.2474$ and $\mathrm{W}=$ $3.0144 \mathrm{~L}^{7.895} \mathrm{R}^{2}=0.769$, respectively. The calculation result for $S$. cucullata in the whole sites was $\mathrm{W}=0.711 \mathrm{~L}^{2.037}$ with $\mathrm{R}^{2}$ value $=0.158$ (Table 2$)$. Based on the graph of the length-weight ratio of $S$. cucullata in Labuhan Haji, Kuala Gigieng and Loskala, it was showed $\mathrm{R}^{2}$ percentage of $18.3 \%, 24.7 \%$ and $76.9 \%$, respectively. The calculation of the weight of $C$. iredalei in Labuhan Haji, Kuala Gigieng and Loskala were $\mathrm{W}=0.765 \mathrm{~L}^{4.923} \mathrm{R}^{2}=0.9623, \mathrm{~W}=$ $0.611 \mathrm{~L}^{1.5909} \mathrm{R}^{2}=0.14$ and $\mathrm{W}=0.3569 \mathrm{~L}^{1.3461} \mathrm{R}^{2}=0.0312$. The calculation of $C$. iredalei for the whole sites was $\mathrm{W}=$ $0.787 \mathrm{~L}^{2.197} \mathrm{R}^{2}=0.384$. The result shows that the percentage of $\mathrm{R}^{2}$ was $96.2 \%$ (Labuhan Haji), 14\% (Kuala Gigieng), 3.12\% (Loskala) and the total was 38.4\%.

\section{Genetic diversity of Saccostrea cuculata and Crassostrea iredalei}

Genotypes analysis of the 77 samples revealed that there are two species of oysters. Sequence analysis of $S$. cucullata and $C$. iredalei using $16 \mathrm{~S}$ mtDNA loci along Aceh waters and 19 additional oyster sequences from China, Japan, and Thailand obtained an indented result of 98-99\%. As many as 96 DNA fragments of oyster were sorted, and there were 445-569 basepairs obtained. The phylogenetic tree shows two large clades namely $S$. cucullata and C. iredalei (Figure 2). The tree shows that the Chinese S.cucullata clade is separated from those of Japanese and Aceh waters with a genetic distance of 0.071 , while the genetic distances among other populations were ranged from 0.006-0.002. The genetic distance among populations of $C$. iredalei is same, while the genetic distance within the population was 0.000 . This value indicates a low genetic distance and close relationship among C. iredalei populations (Nei 1972). The knowledge of genetic distance and the phylogenetic tree can identify the closeness between the two oyster species (Jefri et al. 2015).

Table 3. Genetic diversity of Saccostrea cuculata and Crassostrea iredalei based on haplotype number (Hn), haplotype diversity (Hd), nucleotide diversity, and sample size (n)

\begin{tabular}{lllccc}
\hline \multirow{2}{*}{ Species $\square$} & Population $\square$ & \multirow{4}{*}{ N } & Genetic diversity $\square$ \\
\hline S. cucullata & Labuhan Haji & 27 & 16 & 0.931 & 0.005 \\
& Kuala Gigieng & 13 & 12 & 0.987 & 0.007 \\
& Loskala & 6 & 4 & 0.800 & 0.003 \\
& Japan & 7 & 2 & 0.285 & 0.001 \\
& China & 6 & 6 & 1.000 & 0.024 \\
C. iredalei & Labuhan Haji & 2 & 2 & 1.000 & 0.006 \\
& Kuala Gigieng & 18 & 4 & 0.634 & 0.003 \\
& Loskala & 11 & 3 & 0.618 & 0.003 \\
& Japan & 2 & 1 & 0.000 & 0.000 \\
& Thailand & 4 & 1 & 0.000 & 0.000 \\
\hline
\end{tabular}

Table 2. Length-weight relationship of $S$. cucullata and C. iredalei with sample size (n), constants (a), growth index value (b), correlation value $(\mathrm{r})$, and determinant $\left(\mathrm{R}^{2}\right)$

\begin{tabular}{llcccccc}
\hline Species & Site & $\mathbf{n}$ & $\mathbf{a}$ & $\mathbf{b}$ & $\mathbf{r}$ & $\mathbf{r}^{\mathbf{2}}$ & Growth pattern \\
\hline \multirow{3}{*}{ S. cucullata } & Labuhan Haji & 28 & 0.131 & 2.920 & 0.427 & 0.183 & Negative allometric \\
& Kuala Gigieng & 13 & 0.250 & 2.774 & 0.490 & 0.247 & Negative allometric \\
& Loskala & 6 & 3.014 & 2.895 & 0.840 & 0.769 & Negative allometric \\
& Total & 47 & 0.711 & 2.037 & 0.397 & 0.158 & Negative allometric \\
& & & & & & & \\
& Labuhan Haji & 3 & 0.765 & 4.923 & 0.980 & 0.962 & Positive allometric \\
& Kuala Gigieng & 18 & 0.611 & 1.590 & 0.370 & 0.140 & Negative allometric \\
& Loskala & 11 & 0.356 & 1.346 & 0.170 & 0.031 & Negative allometric \\
& Total & 32 & 0.787 & 2.197 & 0.619 & 0.384 & Negative allometric \\
\hline
\end{tabular}




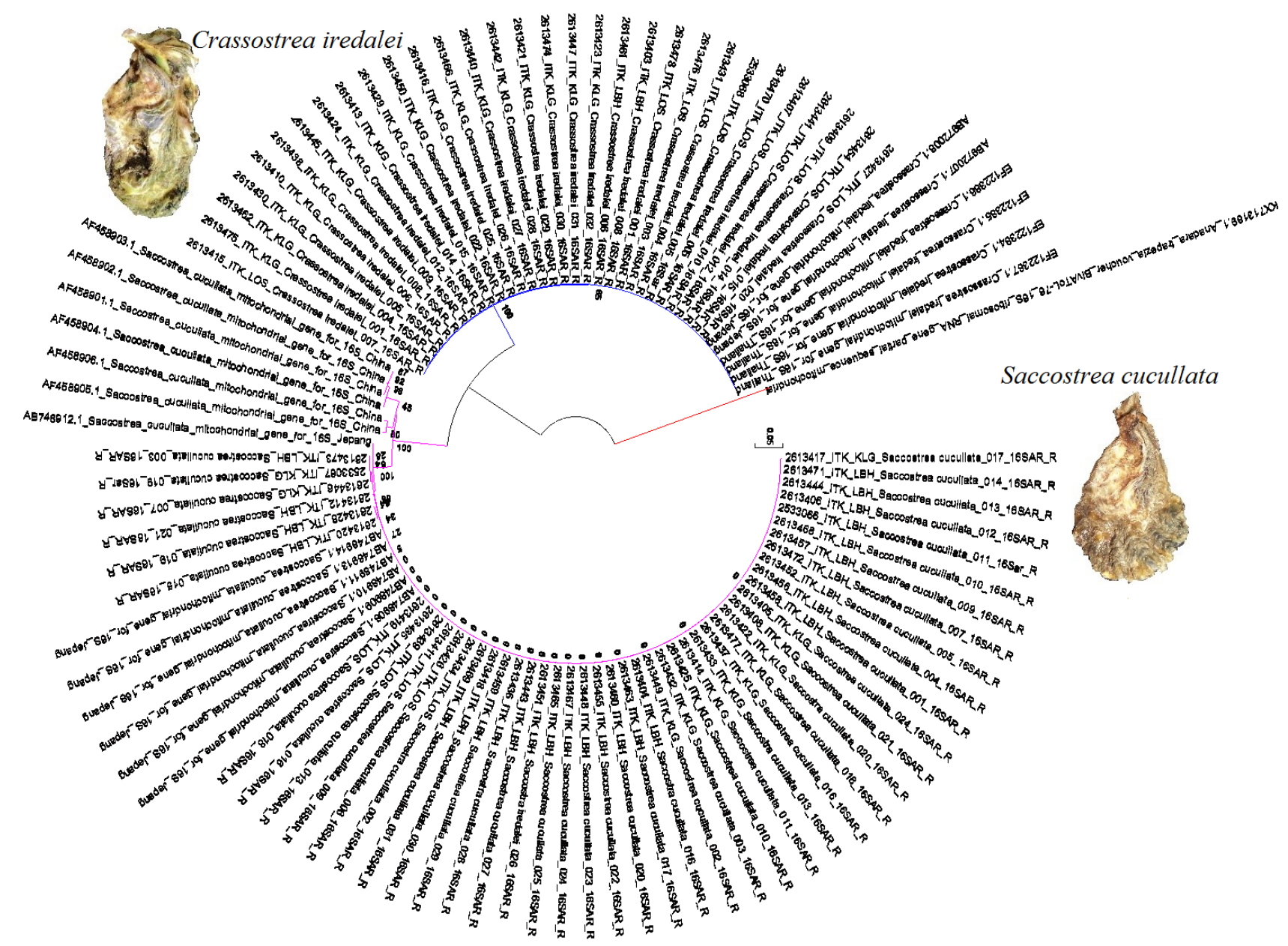

Figure 2. Reconstruction of the phylogenetic tree of S. cucullata dan C. iredalei using Neighbour-Joining method with Kimura 2 parameter model with a bootstrap value of $1000 \mathrm{x}$

The genetic diversity of S.cucullata in each population was fairly high, with an index ranging from 0.800 to 0.987 . The lowest nucleotide diversity was in the Loskala population $(\pi=0.003)$ and the highest in the Kuala Gigieng population $(\pi=0.007)$. The Genetic diversity index of the Chinese oyster population is very high, reaching $1.000(\pi=$ $0.024)$. The Japan oyster population has the lowest genetic diversity compared to other regions, namely $0.285(\pi=$ 0.001) (Table 3).

C. iredalei oyster population sampled from Kuala Gigieng site showed a low genetic and nucleotide diversity $(0.634 ; \pi=0.003)$. Labuhan Haji site showed a higher value of $\mathrm{Hd}$ and $\pi$ of both species per population, (Nei 1987). The highest values of $\mathrm{Hd}$ and $\pi$ in the oyster population of Labuhan Haji station were 1.00 and 0.006 . The Hd and $\pi$ values for Japan and Thailand population showed the lowest value of 0.000 . The nucleotide chains undergoing polymorphisms in $S$. cucullata were 16 , in which 10 nucleotides underwent transition and 6 nucleotides underwent transversion. There were 5 nucleotide substitutions of nucleotides in C. iredalei consisting of 3 nucleotides transition and 2 nucleotides transversion. A nucleotide transition is much more frequent than a nucleotide transversion (Kochzius and Nuryanto 2008).

\section{Genetic population structure}

The evolutionary relationship among 96 oyster samples is shown by the Haplotype network (Figure 4). The results showed that $S$. cucullata had more haplotypes than $C$. iredalei. However, viewed at each population, Kuala Gigien site showed the highest number of $S$. cucullata haplotypes (9 haplotypes), followed by Japan (7 Haplotypes), Labuhan Haji (7 Haplotypes), Loskala (3 Haplotypes) and China (1 Haplotype). Meanwhile, C. iredalei showed 2 haplotypes for Japan, 2 haplotypes for Loskala and 1 haplotype for Labuhan Haji and Kuala Gigieng.

The results of the haplotype network analysis (Figure 4) showed that 7 haplotypes of S. cucullata were present only in Japanese water and 5 haplotypes were present only in Kuala Gigieng population. Other haplotypes could be found in all three populations which indicate that there is a combination of haplotypes among the three populations. However, in the Japanese oyster population, there is no combination with other populations as seen from the haplotype network in which there are many isolations occurred between the Japanese oyster population and other populations. The haplotype 1 was found in all the populations whereas the haplotype 2 was only found in the 
Loskala oyster population. The same results were also shown in the haplotype network of the Japanese oyster population which exhibit more isolation than that of other populations.

The statistical analysis of population structure between and within populations was tested using molecular variance analysis AMOVA (Excoffier et al. 1992) and paired genetic distance test used $\mathrm{F}_{\text {st }}$ value. These molecular statistic calculations used Arlequin software version 3.5.2.2 based on the results obtained from Mega 6 software. The genetic distance value of $S$. cucullata between populations in Aceh waters was 0.003-0.004 (Table 4), while the range of genetic distance within the population was 0.002-0.005. The genetic distance between populations in $C$. iredalei was the same for all stations, with a value of 0.000 . The $F_{\text {st }}$ for $S$. cucullata was $0.708(\mathrm{P}$-value $=0.000)$, whereas that of $C$. iredalei was $0.971(\mathrm{P}$-value $=0.000)$ (Table 5). The $\mathrm{F}_{\text {st }}$ values of these two species belong to the high category of 0.6-1.00 (Excoffier et al. 1992).

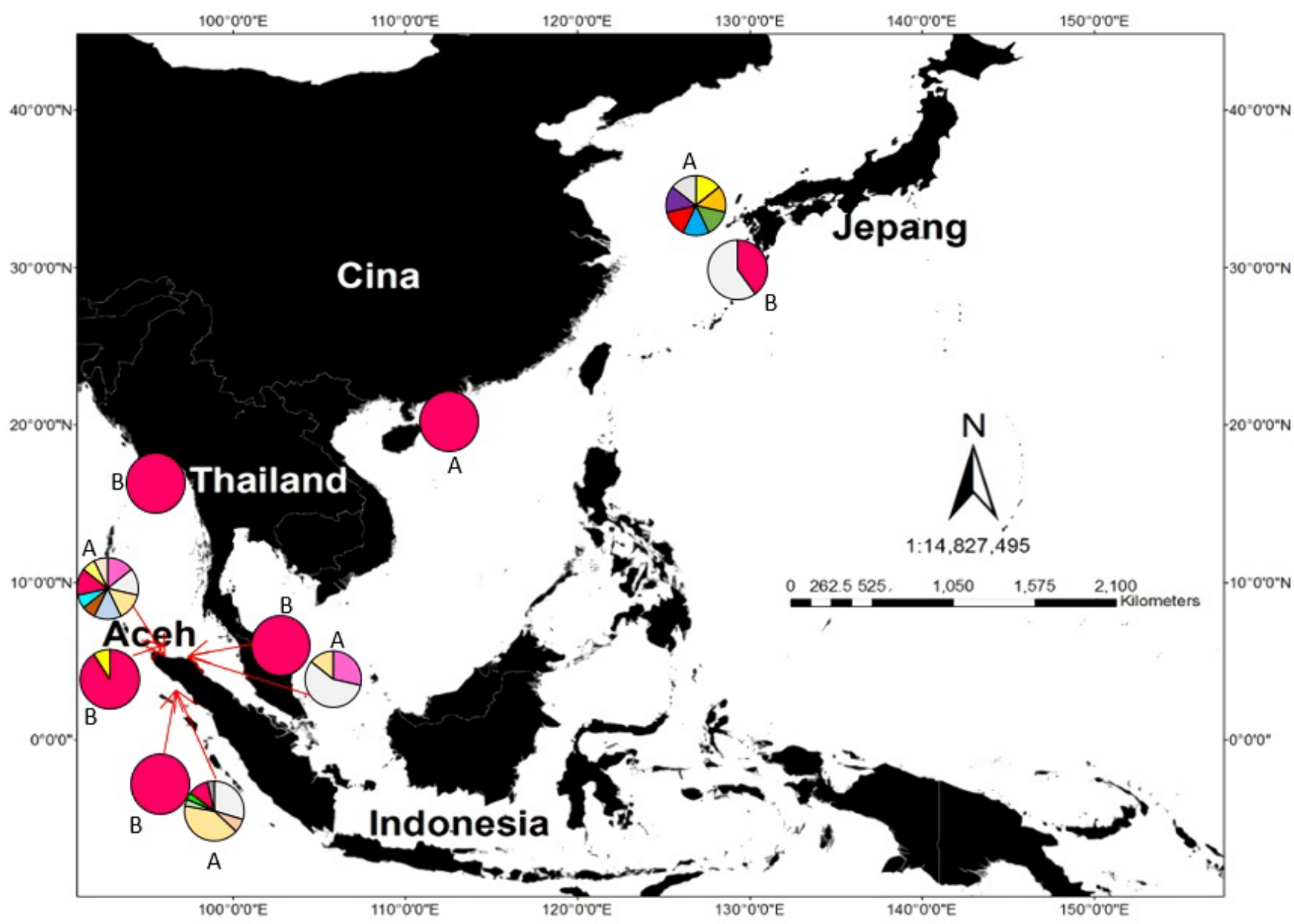

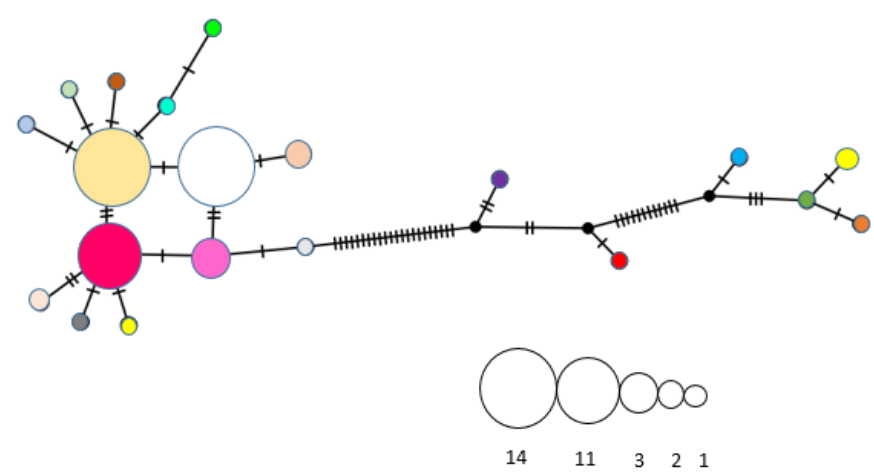

A

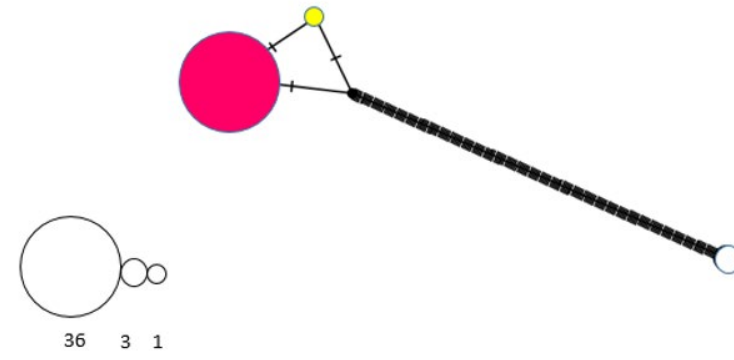

B

Figure 4. Haplotype network of Sacrosstrea cucullata (A), Crassostrea iredalei (B) in each population. The circle line demonstrates the presence of change in nucleotides and the circle size illustrates the frequency of change in haplotype composition 
Table 4. Genetic distances analysis between and within populations of Sacrosstrea cuculata and Crassostrea iredalei for the whole populations

\begin{tabular}{rlcccccc}
\hline \multicolumn{1}{c}{ Species } & \multicolumn{1}{c}{ Population } & Labuhan Haji & Kuala Gigieng & Loskala & Japan & China & Thailand \\
\hline S. cucullata & Labuhan Haji & 0.003 & - & - & - & - & - \\
& Kuala Gigieng & 0.004 & 0.005 & - & - & - & - \\
& Loskala & 0.003 & 0.004 & 0.002 & - & - & - \\
& Japan & 0.005 & 0.004 & 0.006 & 0.001 & - & - \\
& China & 0.071 & 0.071 & 0.071 & 0.067 & 0.024 & - \\
C. iredalei & Labuhan Haji & 0 & - & - & - & - & - \\
& Kuala Gigieng & 0 & 0 & - & - & - & - \\
& Loskala & 0 & 0 & 0 & - & - & - \\
& Japan & 0 & 0 & 0 & 0 & - & - \\
& Thailand & 0 & 0 & 0 & 0 & - & 0 \\
\hline
\end{tabular}

Table 5. Pairwise Fst values between and within populations of Sacrosstrea cuculata and Crassostrea iredalei

\begin{tabular}{llcccc}
\hline Species $\square$ & $\begin{array}{l}\text { Source of } \\
\text { variation }\end{array}$ & d.f. & $\begin{array}{c}\text { Variation } \\
\mathbf{( \% )}\end{array}$ & Fst & $\begin{array}{c}\text { P- } \\
\text { value }\end{array}$ \\
\hline S. cucullata & $\begin{array}{l}\text { Within a } \\
\text { population } \\
\text { Between } \\
\text { populations }\end{array}$ & 4 & 70.84 & 0.708 & 0 \\
& Total & 58 & 29.16 & & \\
C. iredalei & $\begin{array}{l}\text { Within a } \\
\text { population } \\
\text { Between } \\
\text { populations } \\
\text { Total }\end{array}$ & 4 & 97.10 & 0.971 & 0 \\
& 36 & 2.90 & & \\
& & & & & \\
\hline
\end{tabular}

\section{Discussion}

Allometric growth of the oyster populations in Aceh

Morphometric characters are measured to know the morphological variations within a species resulted from the difference in environmental conditions and the availability of nutrient in the environment (Chiu et al. 2002). Allometric growth is defined as the increase in size of different organs or parts of an organism at various rates (Gould 1966). Morphometric measurements can give information on the stock composition, age at maturity, life span, mortality, growth, and production (Beyer 1987; Bolger and Connoly 1989; King 1996; Diaz et al. 2000). The total morphometrics showed $b<3$ for the three observation populations. This $\mathrm{b}$ value of $S$. cucullata indicates a faster increase in the length of the oyster shell compared to its weight gain, manifested in very thin body size. Effendie (1997) stated that $b<3$ indicates an allometric growth in which the increase in body length is faster than the increase in body weight. Interestingly, oyster populations from Labuhan Haji showed $b>3$ which means the increase in the total weight of the oyster shell is faster than that of the shell length. These results suggest that the number of samples may also affect the $b$ value. The oyster length and total weight of $C$. iredalei showed $\mathrm{b}<3$ in all observation sites. Overall, our morphometric analysis showed that the growth of the two oyster species in all three stations is classified as negative allometric. Negative allometric growth is the disproportionate growth of parts of an organism as the organism changes in size, in this case, the growth of the oyster shell length is faster than that of the body weight. (Gaspar et al. 2002). Octavina et al. 2014 found that oysters in Kuala Gigieng Station showed a negative allometric growth pattern.

We observed that oysters measured in this study were young oysters and still in the growth stage. This finding was likely due to rapid and continuous consumption of adult oysters in the area. Oysters are hermaphrodite animals (Satino 2003). According to Wang et al. (2004), oysters are born as males until they are able to release sperm, then they will turn into females if environmental condition is suitable (Galtsoff 1964). During this male phase, the oysters focus their growth on the elongation of the shell and sperm production, before lately turn into female oysters (Yang et al. 2014). When a male oyster turns into a female, the oyster will focus its growth on gaining the body weight. Therefore females tend to be heavier than males (Needler 1941). The change of sex in oyster is strongly influenced by the environment (Fulford et al. 2010). If the environmental condition is not conducive, for example, food crisis or population explosion, then the oyster will tend to stay male. This situation might result in a decrease in oyster population that would severely disrupt both their ecological and economic functions (Octavina et al. 2014). In the case of Labuhan Haji site, the growth of oysters was allometric positive because at this station the oysters are not consumed and sold. The difference in the growth rate in the three observation sites is due to the different growth rate of individuals composing each population. Every individual has their own capacity in utilizing energy and minimizing the effect of physiological and other factors (Dody 2010).

\section{Genetic diversity of Saccostrea cuculata and Crassostrea iredalei}

DNA analysis has been a successful approach to solving the problem of species identification. In addition, DNA analysis is also capable of answering questions that have not been able to be answered by the morphological analysis approach (Reeb and Avise 1990; Boom et al. 1994; Small and Chapman 1988; Boudry et al. 1998). In 
this study, we reconstructed a phylogenetic tree from the three observation stations using the Neighbour-joining method and evaluate it with a bootstrap of 1000x. The distance calculation is based on Kimura 2 parameter method (Tamura et al. 2013), because this option considers the nucleotide transition and transversion rates (Jefri et al. 2015). Neighbor-joining trees obtained from molecular analysis not only solve some taxonomic issues but also identify patterns of biogeographic distribution (Lam and Morton 2005). The sequences of $S$. cucullata and C.iredalei from several countries obtained from GenBank are also used in this analysis to see the grouping of all sequences. Furthermore, the out-group included in this analysis come from the same class that is Anadara Trapezia. The constructed phylogenetic tree has two large clades namely $S$. cucullata and $C$. iredalei. Clade $S$. cucullata is separated into 2 sub-clusters namely oysters from Aceh waters and Japanese waters with a bootstrap value of 80 and oyster from Chinese waters with a bootstrap value of 45 . Meanwhile, $C$. iredalei sequences from Japan and Thailand grouped into one large clade together with $C$. iredalei originated from Aceh waters with a bootstrap value of 65 . The phylogenetic trees can be clarified by the genetic distance value of Saccostrea cucullata which is relatively high compared to Crassostrea iredalei. The genetic distance is determined by the amount of base undergone changes (Ubaidillah and Sutrisno 2009), the more the differences, the more mutations occur which lead to far genetic distance. Oysters are a type of sessile animal that can only mobile during their larval period with the help of water currents of their original habitat (Seliger et al. 1982). In general, overly large oysters will be distributed more widely compared with the less large oysters. For example, Saccostrea cucullata can be found in tropical indo-pacific whereas Crassostrea iredalei is only found in the South China Sea, Andaman Sea and Gulf of Thailand (Yoosukh and Duangdee 1999). The genetic distance of $C$. iredalei population is low probably because this oyster is not a native biota of Indonesia but originally from the Philippines (Poutiers 1998). From the Philippines, the larva disperses and reach Indonesia and the surrounding waters, causing a very limited gene flow. In contrast, $S$. cucullata has a very wide geographical range in which the larva is originated from the Indo-Pacific and disperse to South Africa (Poutiers 1998), the Malay Archipelago and North Australia (Buroker 1985); therefore, the gene has high heterozygosity level (Permana et al. 2006).

Nucleotide composition of $S$. cucullata species was 26.5\% (Thymine), 18.1\% (Cytosine), 28.9\% (Adenine) and $26.5 \%$ (Guanine). The biggest nucleotide composition was the $\mathrm{A}+\mathrm{T}$ pair with the average amount of $27.7 \%$ while the lowest was the pair $\mathrm{G}+\mathrm{C}$ with the average amount of 22.3. The $C$. iredalei showed an average nucleotide composition of $29.6 \%$ (Thymine), $16.2 \%$ (Cytosine), 29.4\% (Adenine) and $24.8 \%$ (Guanine). The most predominant nucleotide pair was the pair A $+\mathrm{T}$ with a frequency of $29.5 \%$, and the lowest was the $\mathrm{G}+\mathrm{C}$ pair with an average amount of $20.5 \%$. If two different species have more $A+T$ base composition, then the species will have many similarities because of the independent parallel substitution.
Consequently, they will be grouped by the similarity in their base composition (Lam and Morton 2006). Therefore, the similarity in nucleotide composition may explain morphological similarities observed on the two oyster species, and hence it is very difficult to distinguish them morphologically.

There are several mutation-driven nucleotide polymorphisms in the two oyster species (Ubaidillah and Sutrisno 2009). There are two types of nucleotide substitution mutation namely transition and transversion. The transition is the change between Adenine and Guanine (Purine) or between Citocyne and Thymine (pyrimidine), while transversion is the change between purine or pyrimidine (Ubaidillah and Sutrisno 2009). The polymorphisms occurred in the nucleotide chain of S.cucullata were 10 nucleotide transitions and 6 transversions. Nucleotide substitutions in $C$. iredalei occurred in 5 nucleotides of which 3 were transitions and 2 were transversions. Nucleotide transition is more predominant than transversion (Kochzius and Nuryanto 2008). Mollusks living in the sea have high levels of polymorphism due to the widespread of larvae, abundant populations and extensive dispersal (Ward et al. 1992; Bazin et al. 2006). Mutation or gene variation in population has proven to be very useful as an indicator for the population structure and is particularly sensitive to reproductive restrictions (Chapman 1989; Boom et al. 1994). Genetic variation and genetic diversity are important and has been linked to organismal complexity (Lynch and Conery 2003), long-term population survival in ecosystem recovery (Reusch et al. 2004), and species adaptability to environmental changes (Ellegren and Galtier 2016; O'brien 1994). Heterozygosity in many cases is considered the primary parameter to reflect the overall population genetic variability (Zhong et al. 2016).

Several comparative studies have demonstrated the diversity of Tridacna crocea haplotype ranging from 0.77 to 1.00 (Kochzius and Nuryanto 2008); the diversity of $S$. cucullata 0.6285 and $C$. iredalei 0.1857 (Klinbunga et al. 2005). In this study, the nucleotide diversity of $S$. cucullata $(\pi=0.3501)$ and $C$. iredalei $(\pi=0.09)$ are low compared to that of the previous report by Klinbunga et al. 2005. Based on the Hd and $\pi$ values of both species per population, the Labuhan Haji population showed a higher average value. This is because oysters in Labuhan Haji are not exploited as heavily as those in the other observation stations wherein oysters become the livelihood of the local people. Exploitation is one of the key factors that determine the number of haplotypes and the nucleotide diversity in a population (Kochzius and Nuryanto 2008).

\section{Genetic population structure and connectivity}

The goal of population genetics is to understand the processes that influence the interconnectivity among populations of a species as a result of local adaptation, and eventually speciation based on the genetic structure (Fauvelot et al. 2003). The results of haplotype diversity analysis indicate a close relationship between oysters in all populations, haplotype diversity closely related to genetic diversity. Another factor that might influence close genetic 
distance between populations is the absence of geographic complexity (Avise 1992). Oceanographic factors such as currents and tides have contribution to the pattern of dissemination and recruitment of marine biota (Findly and White 2003). The ocean current is different from place to place. This difference is probably caused by the irregular current movements within a year in the study sites. Ocean currents change every half year and correspond to the movement of the seasonal wind, resulting in even larval distribution to the north and south (Sverdrup et al. 1942). The larvae from these oysters can easily be carried away by the Indian Ocean currents along the Aceh coast which are only distinguished by the small current patterns between the Malacca Strait and the Andaman Sea. Those oceanographic factors might have maintained high and relatively similar levels of genetic diversity between populations. The tidal currents in the Indonesian waters are strong and affect the vertical water mass mixing. Potential factors that play a role in organism distribution are the current conditions and duration of larvae in the waters (Saleky et al. 2016).

The isolation observed in the Japanese oyster population is due to the genetic distance. The cycle of cold currents surrounding Japanese waters keeps the sessile biota that relies on their larval period to find a rich habitat in food supplies to remain in the vicinity of the Japanese waters. The Japanese water is flanked by two types of currents, namely Oyashio and Kuroshio currents (Nomura and Yamazaki 1977; Nomura 1991). The Oyashio is a cold current that moves from the southern Pacific Ocean, while the Kuroshio is a hot current that moves from the North Coast of Japan (Buesseler et al. 2011). Both currents are from the North Pacific Currents. The Kuroshio current is the continuation of the northern equatorial currents: after arriving in the Philippines, the direction of the current goes to the north and its movement is driven by the west wind.

Based on the results a very high-level $F_{\text {st }}$ test and the genetic distance (Table 5) showing that the population was highly structured. The Fst shown in this study much higher than observed by Wang et al. (2004) reported that the $F_{\text {st }}$ value of oysters in Chinese waters ranged from 0.0036 0.2705 . This value tends to be high because there were large numbers of the oyster species found in this region, leading to high genetic diversity and in accordance to the population structure $\left(F_{s t}\right)$ (Wang et al. 2004). The genetic distance is determined by the amount of base that undergoes changes. The more the difference, the higher the mutation frequency, and the farther the distance (Ubaidillah and Sutrisno 2009). The greater the value of the genetic distance, the greater the gene flow into a population, so it can be explained that the current lion's share in the genetic distribution of each population. Gene flow is associated with the geographic isolation that is affected by the geographical distance and complexity of environmental diversity (Arnaud et al. 1999).

This study concludes that the growth pattern of $S$. cucullata and $C$. iredalei is negative allometry. This finding shows that the environmental impact might directly affect the oyster genetic structure. This genetic diversity in $S$. cucullata and C. iredalei indicates the presence of gene flow in each population and their contribution in response to different environmental conditions. The population structure and phylogenetic reconstruction suggest that oysters from Aceh waters originated from the same population and had the same dispersal pattern because of the close geographic distance and the connection of a direct current pattern. S. cucullata and C. iredalei oysters from China, Thailand and Aceh waters have the same haplotype, demonstrating the presence of the respective gene (mtDNA $16 \mathrm{~S})$ in their populations.

Research on the population structure and genetic diversity of $S$. cucullata and $C$. iredalei may be helpful in developing conservation management because environment strongly affects oyster growth. This information may also increase the awareness of fishermen on oyster sustainability and educate them to be more selective in catching oysters and developing oyster cultivation systems.

\section{ACKNOWLEDGEMENTS}

We would like to thank the Lembaga Dana Dana Pendidikan (LPDP) for providing scholarships for the completion of this research and paper. Thanks to Marine Biodiversity and Biosystematics Laboratory, Marine Science and Technology, Institut Pertanian Bogor (IPB), Bogor, Indonesia which has facilitated the completion of this research. Thanks also to the village heads of Labuhan Haji, Kuala Gigieng and Loskala who have allowed and helped to facilitate the oyster sampling.

\section{REFERENCES}

Akbar N, Zamani NP, Madduppa HH. 2014. Genetic diversity of yellowfin tuna (Thunnus albacares) from two populations in the Moluccas Sea, Indonesia. Depik 3: 65-73.

Arnaud JF, Madec L, Bellido A, Guiller A. 1999. Microspatial genetic structure in the Land Snail Helix aspersa (Gastropoda: Helicidae). Heredity 83: 110-119

Avise JC. 1992. Molecular population structure and the biogeographic history of a regional fauna: a case history with lessons for conservation biology. Oikos 63: 62-76.

Bandelt HJ, Forster P, Rohl A. 1999. Median-joining networks for inferring intraspecific phylogenies. Mol Biol Evol 16 (1): 37-48

Banks M, Hedgecock AD, Waters C. 1993. Discrimination between closely related Pacific oyster species (Crassostrea) via mitochondrial DNA sequences coding for large subunit rRNA. Mol Mar Biol Biotechnol 2 (3): 129-136.

Bazin E, Glemin S, Galtier N. 2006. Population size does not influence mitochondrial genetic diversity in animals. Science. 312: 570.

Beyer JE. 1987. On length-weight relationship. Part 1. Corresponding the mean weight of a given length class. Fishbytes 5 (1): 11-13

Bolger T, PL Connoly. 1989. The selection of suitable indices for the measurement and analysis of fish condition. J Fish Biol 34: 171-182.

Boom JDG, Boulding EG, Beckenbach AT. 1994. Mitochondrial DNA variation in introduced populations of Pacific oyster, Crassostrea gigas in British Columbia. Canadian J Fish Aquat Sci 51:1608-1614.

Boudry P, Heurtebise S, Collet B, Cornette F, Gerard A. 1998.Differentiation between populations of the Portuguese oyster, Crassostrea angulata (Lamarck) and the Pacific oyster, Crassostrea gigas (Thunberg), revealed by mtDNA RFLP analysis. J Exp Mar Biol Ecol 226: 279-291.

Boudry P, Heurtebise S. Lapegue S. 2003. Mitochondrial and nuclear DNA sequence variation of presumed Crassostrea gigas and Crassostrea angulata specimens: A new oyster species in Hong Kong. Aquaculture 228: 15-25 
Buesseler K, Aoyama M, Fukasawa M. 2011. Impacts of the Fukushima nuclear power plants on marine radioactivity. Environ Sci Techno 45: 9931-9935

Buroker, Norman E. 1985. Evolutionary patterns in the Family Ostreidae: Larviparity vs oviparity. J Exp Mar Biol Ecol 90 (3): 233-247

Bussarawit S, Gravlund P, Glenner H, Rasmussen, AR. 2006. Phylogenetic analysis of Thai oyster (Ostreidae) based on partial sequences of the mitochondrial 16S rDNA gene. Phuket Marine Biological Center. Res Bull 67 (1-9): 1-9.

Chapman RW. 1989. Mitochondria and nuclear gene dynamics of introduced populations of Lepomis macrochirus. Genetics 123: 399 404.

Chiu Y, Chen H, Lee S, Chen CA. 2002. Morphometric analysis of shell and operculum variations in the viviparid snail Cipangopaludina chinensis (Mollusca: Gastropoda) in Taiwan. Zool Stud 41 (3): 321 331

Christo SW, Absher TM, Boehs G. 2010. Morphology of the larval shell of three tiram species of Genus Crassostrea Sacco, 1897 (Bivalvia: Ostreidae). Brazilian J Biol 70 (3): 645-650.

Dharma B. 2005. Recent \& Fossil Indonesian Shell. PT. Ikrar Mandiriabadi, Jakarta, Indonesia.

Diaz LS, Roa A, Garcia CB, Acero A, Navas G. 2000. Length-weight relationships of demersal fishes from the upper continental slope off Colombia. ICLARM Quart 23 (3): 23-25.

Dody S. 2010. Morfometrik dan pertumbuhan kerang tapes (Tapes literatus) di Pulau Fair, maluku Tenggara. Prosiding Seminar Riptek Kelautan Nasional, Ancol Timur. Jakarta. [Indonesian]

Effendie MI. 1997. Biologi Perikanan. Yayasan Pustaka Nusatama, Yogyakarta. [Indonesian]

Ellegren H,Galtier N. 2016. Determinants of genetic diversity. Nature Rev Genet 17 (7): 422-433.

Excoffier L, Smouse PE, Quattro JM. 1992. Analysis of moleculer variance inferred from metric distance among DNA haplotipes; application to human mitochondrial DNA restriction data. Genetics 131: 479-491.

Fauvelot C, Bernardi G, Planes S. 2003. Reductions in the mitochondrial DNA diversity of coral reef fish provide evidence of population bottlenecks resulting from Holocene sea-level change. Evolution 57 (7): 1571-1583.

Findly JM, White SJ. 2003. Serial programming for saccades: does it al add up?. Behav Brain Sci 26: 483-484.

Fulford RS, Breitburg DL, Luckenbach M, Newell RIE. 2010. Evaluating ecosystem response to oyster restoration and nutrient load reduction with a multispecies bioenergetics model. Ecol Appl 20: 915-934.

Galtsoff PS.1964.The American oyster, Crassostrea virginica Gmelin, Fishery Bulletin, Vol. 64. United States Government Printing Office, Washington, D.C.

Gaspar MB, Santos MN, Vasconcelos P, Monteiro CC. 2002. Shell morphometric relationships of the most common bivalve species (Mollusca: Bivalvia) of the Algarve coast (Southern Portugal) Hydrobiologia. 477: 73-80

Gosling E. 2003. Bivalve Molluscs. Fishing News Books. London, UK.

Gould SJ. 1966. Allometry and size on ontogeny and phylogeny. Biol Rev 41: 587-640.

Grassle JF. 1972. Species diversity, genetic variability, and environmental uncertainty. In: Battaglia B. (ed.). Fifth European Marine Biology Symposium. 19-26 October 1970, Italy.

Gunter G. 1950. The genetic status of living oysters and the scientific name of the common American species. Amer Midland Nat 143: 438449.

Hajibabaei M, Singer GAC, Hebert PDN, Hickey DA. 2007. DNA barcoding: How it complements taxonomy, molecular phylogenetics, and population genetics. Trends Genet 23 (4): 167-172.

Hebert PDN, Cywinska A, Ball SL, De Waard JR. 2003. Biologica identifications through DNA barcodes. Proc R Soc London Ser B Biol Sci 270 (1512): 313-321.

Hedgecock EM, Herman RK. 1995. The ncl-1 gene and genetic mosaics of Caenorhabditis elegans. Genetics 141 (3): 989-1006.

Hudson RR, Slatkin M, Maddison WP. 1992. Estimation of levels of gene flow from DNA sequence data. Genetics 132: 583-589.

Jefri E, Zamani NP, Subhan B, Madduppa HH. 2015. Molecular phylogeny inferred from mitochondrial DNA of the groupe Epinephelus spp. in Indonesia collected from local fish market. Biodiversitas 16: 254-263.

Jiafeng W, Fei X, Li L, Goufan Z. 2014. A new identification method for five species of oysters in Genus Crassostrea from China based on high-resolution melting analysis. Chinese J Oceanol Limnol 32 (2): 419-425.

King RP. 1996. Length-weight relationships of Nigeria Freshwater fishes. Naga ICLARIM Q 19 (3): 49-52.

Klinbunga S, Khamnamtong N, Puanglarp N, Jarayabhand P, Yoosukh W, Manasveta P. 2005. Molecular taxonomy of cupped oysters (Crassostrea, Saccostrea, and Striostrea) in Thailand based on COI, 16S, and 18S rDNA polymorphism. Mar Biotechnol 7: 306-317.

Kochzius M, Nuryanto A. 2008. Strong genetic population structure in the boring giant clam Tridacna crocea, across the Indo-Malay Archipelago: implications related to evolutionary processes and connectivity. Mol Ecol 17: 3775-3787.

Kusuma AB, Bengen DG, Madduppa H, Subhan B, Arafat D. 2016. Keanekaragaman genetik karang lunak Sarcophyton trocheliophorum pada populasi Laut Jawa, Nusa Tenggara dan Sulawesi. Jurnal Enggano 1 (1) 89-96. [Indonesian]

Lam K, Morton B. 2003. Mitochondrial DNA and morphological identification of a new species of Crassostrea (Bivalvia, Ostreidae) cultured for centuries in the Pearl River Delta, Hong Kong, China. Aquaculture 228: 1-13.

Lam K, Morton B. 2006. Morphological and mitochondrial-DNA analysis of the Indo-West Pacific rock oysters (Ostreidae: Saccostrea species). J Molluscan Stud 72: 235-245.

Liu J, Li Q, Kong L, Yu H, Zheng X. 2011. Identifying the true oysters (Bivalvia: Ostreidae) with mitochondrial phylogeny and distancebased DNA barcoding. Mol Ecol Resour 11 (5): 820-830.

Lynch M, Conery JS. 2003. The origins of genome complexity. Science 302 (564): 1401-1404

Madduppa H, Ayuningtyas RU, Subhan B, Arafat D, Prehadi. 2016. Exploited but unevaluated: DNA Barcoding reveals skates and stingrays (Chordata, Chondrichthyes) species landed in the Indonesian fish market. Indon J Mar Sci 21 (2): 77-84

Madduppa H, Taurusman AA, Subhan B, Anggraini NP. 2017. Short Communication: DNA barcoding reveals vulnerable and not evaluated species of sea cucumbers (Holothuroidea and Stichopodidae) from Kepulauan Seribureefs, Indonesia. Biodiversitas 18 (3): 893-898

Madduppa HH, Timm J, Kochzius M. 2014. Interspecific, spatial and temporal variability of self-recruitment in anemonefishes. PLoS One. 9 (6): e101396. DOI: 10.1371/journal.pone.0090648

Mass PAY, Mullan GDO, Lutz RA, Vrijenhoek RC. 1999. Genetic and morphometric characterization of mussels (Bivalvia: Mytillidae) from Mid-Atlantic Hydrothermal Vents. Biol Bull 196 (3): 265-272.

Maulid DY, Nurilmala M, Madduppa H. 2016. Karakteristik molekuler Cytochrome B untuk DNA barcoding ikan tenggiri. Jurnal Pengolahan Hasil Perikanan Indonesia 19 (1): 9-16. [Indonesian]

Needler AB. 1941. Sex reversal in individual oysters. J Fish Res Board Canada 5b: 361-364.

Nei M, JinL. 1989. Variances of the average numbers of nucleotides substitutions within and between populations. Mol Biol Evol 6: 290300.

Nei M. 1972. Genetic distance between population. Amer Nat 106:283292.

Nei M. 1987. Molecular Evolutionary Genetics. Columbia University Press. New York.

Nomura M, Yamazaki T. 1977. Fishing Techniques (1). Japan International Cooperation Agency, Tokyo.

Nomura M. 1991. Fishing Techniques (4). Japan International Cooperation Agency, Tokyo.

Nurhayati. 2009. Stuktur pola pergerakan arus dan pengaruhnya pada orientasi kelimpahan ikan di perairan Selat Benggala Banda Aceh. Lingkungan Tropis 5 (1): 45-52. [Indonesian]

Octavina C, Yulianda F, Krisanti M. 2014. Struktur komunitas tiram daging di perairan estuaria Kuala Gigieng, Kabupaten Aceh Besar, Provinsi Aceh. Depik 3 (2): 108-117. [Indonesian]

Permana GN, Hutapea JH, Haryanti. 2006. Polimorfisme enzim glucose6-phosphate isomerase pada tiga populasi ikan tuna sirip kuning (Thunnus albacares). J Fish Sci 8 (1): 50-56. [Indonesian]

Poutiers, JM. 1998 Bivalves. Acephala, Lamellibranchia, Pelecypoda. In: Carpenter KE, Niem VH (eds.). FAO Species Identification Guide for Fishery Purposes. The Living Marine Resources of the Western Central Pacific. Volume 1. Seaweeds, Corals, Bivalves, and Gastropods. FAO, Rome.

Prehadi, Sembirin A, Kurniasih EM, Rahmad R, Arafat D, Subhan B, Madduppa H. 2015. DNA barcoding and phylogenetic reconstruction 
of shark species landed in Muncar fisheries landing site in comparison with Southern Java fishing port. Biodiversitas 16 (1): 55-61.

Reeb CA, Avise J. 1990. A genetic discontinuity in a continuously distributed species: Mitochondrial DNA in the American Oyster, Crassostrea virginica. Genetics 124 (2): 397-406

Reusch TBH, Ehlers A, Hammerli A, Worm B. 2004. Ecosystem recovery after climatic extremes enhanced by genotypic diversity. Proc Natl Acad Sci USA 102 (8): 2826-2831.

Ruesink JL, Lenihan HS, Triamble AC, Heiman KW, Micheli F, Byers JE, Kay MC. 2005. Introduction of non-native oysters: ecosystem effects and restoration implications. Ann Rev Ecol Evol Syst 36: 643689.

Saleky D, Setybudiandi I, Toha HA, Takdir M, Madduppa HH. 2016 Length-weight relationship and population genetic of two marine gastropods species (Turbinidae: Turbo sparverius and Turbo bruneus) in the Bird Seascape Papua, Indonesia. Biodiversitas 17 (1): 208-217.

Sanger F, Nicklen S, Coulson AR. 1977. DNA sequencing with chainterminating inhibitors. Proc Natl Acad Sci USA 74 (12): 5463-5467.

Schneider S, Roessli D, Excoffier L. 2000. Arlequin Version 2.000 University of Geneva, Geneva, Switzerland.

Sekino M, Ishikawa H, Fujiwara A, Doyola-Solis EFC.Lebata-Ramos MJH, Yamashita H. 2014. The first record of a cupped oyster species Crassostrea dianbaiensis in the waters of Japan. Fish Sci. DOI: 10.1007/s12562-014-0838-3

Sekino M, Yamashita H. 2013. Mitochondrial DNA barcoding for Okinawan oysters: a cryptic population of the Portuguese oyster Crassostrea angulata in Japanese waters. Fish Sci 79: 61-76.

Seliger HH, Boggs JA, Riukin RB, Biggley WH, Aspolen KRH. 1982. The transport of tiram larvae in an estuary. Mar Biol 71: 57-52.

Small MP, Chapman RW. 1988. Intraspecific variation in the $16 \mathrm{~S}$ ribosomal gene of Crassostrea virginica. Mol Mar Biol Biotechnol 6 (3): $189-196$
Sulistiyarto B, Sedharma D, Rahardjo MF, Sumardjo. 2007. Pengaruh musim terhadap komposisi jenis dan kelimpahan ikan di Rawa Lebak, Sungai Rungan, Palangkaraya, Kalimantan Tengah. Biodiversitas 8 (4): 270-273. [Indonesian]

Tamura K, Stecher G, Peterson D, Filipski A, Kumar S. 2013. Mega 5: Molecular Evolution Genetics Analysis, version 6.0. Mol Biol Evol 30: $2725-2729$.

Taylor DR, Aarssen LW. 1988. An interpretation of phenotypic plasticity in Agropyron repens (Gramineae). Amer J Bot 75: 401-413.

Ubaidillah R, Sutrisno H. 2009. Pengantar Biosistematika: Teori dan Praktek. LIPI Press, Jakarta. [Indonesian]

Wang H, Guo X, Zhang G, Zhang F. 2004. Classification of Jinjiang oysters Crassostrea rivularis (Gould, 1861) from China, based on morphology and phylogenetic analysis. Aquaculture 242: 137-155

Ward SM, Sanders KM. 1992. Upstroke component of electrical slow waves in canine colonic smooth muscle due to nifedipine-resistant calcium current. J Physiol 455 (1) 321-337.

Yang H, Wang Y, Guo X, Tiersch TR. 2014. Production of inbred larvae through sel-fertilization using oocytes and cryopreserved sperm from the same individuals after sex reversal in eastern oyster Crassostrea virginica. Aquacult Res 46: 2153-2165.

Yoosukh W, Duangdee T. 1999. Living oysters in Thailand. In: Phuket Marine Biological Center Special Publication No. 19. Phuket, Thailand.

Yoosukh W, Duangdee T. 1999. Living Oysters in Thailand. Phuket, (Thailand: Phuket Marine Biological Center) 19:363-370.

Zhong X, Feng D, Yu H, Kong L, Li Q. 2016. Genetic variation and breeding signature in mass selection lines of the Pacific oyster (Crassostrea gigas) assessed by SNP markers. PLoS One 11 (3): e0150868. DOI: 10.1371/journal.pone. 0150868 . 